\title{
Spectrum of movement disorders in mitochondrial diseases
}

\author{
Olimpia Musumeci, Rosaria Oteri, Antonio Toscano \\ Unit of Neurology and Neuromuscular Disorders, Department of Clinical and Experimental Medicine, University of Messina, \\ Messina 95125, Italy.
}

Correspondence to: Dr. Olimpia Musumeci, Department of Clinical and Experimental Medicine, AOU Policlinico G. Martino, UOC Neurologia e Malattie Neuromuscolari, via Consolare Valeria 1, Messina 95125, Italy. E-mail: omusumeci@unime.it

How to cite this article: Musumeci O, Oteri R, Toscano A. Spectrum of movement disorders in mitochondrial diseases. $J$ Trans/ Genet Genom 2020;4:221-37. http://dx.doi.org/10.20517/jtgg.2020.22

Received: 2 Mar 2020 First Decision: 7 Apr 2020 Revised: 1 May 2020 Accepted: 15 Jun 2020 Available online: 24 Jun 2020

Science Editor: Andrea L. Gropman Copy Editor: Cai-Hong Wang Production Editor: Tian Zhang

\begin{abstract}
Mitochondrial disorders (MD) include a large group of maternally inherited, autosomal dominant, or recessive genetic syndromes caused by mitochondrial dysfunction. MD can be diagnosed at any age and many of them show a multisystem presentation with variable combinations of symptoms. Given the important role of mitochondria in neuronal homeostasis, neurological manifestations, including movement disorders, can accompany MD. Movement disorders $(M \circ D)$, either hypo- or hyperkinetic type, are reported in MD, but the real incidence and a detailed characterization of these features are not addressed in population-based studies. Dystonia, usually in the context of Leigh syndrome, is the main extrapyramidal movement disorder in pediatric MD patients; whereas parkinsonism is the most prevalent hypokinetic disorder in adult MD patients. Ataxia is a common feature in MD, in both the pediatric and adult MD populations. Other MoD, such as myoclonus, chorea, or tremor, may also occur in MD. MoD manifest more frequently in the context of a complex phenotype but rarely can be isolated. From a genetic point of view, MoD are described in patients with either mutations in mtDNA or in nuclear genes related to mitochondria, and the same gene can be associated with different types of MoD. Recent studies demonstrate that the dopaminergic nigrostriatal system is very vulnerable to mitochondrial dysfunction and defects of mtDNA maintenance are frequently associated with a nigrostriatal degeneration, which may explain the pathophysiological mechanism. Therapeutic interventions for MoD in MD do not differ from treatment options used for MoD with different etiopathological background. Some forms benefit from specific treatments, e.g., primary Coenzyme Q10 deficiencies. Newer therapeutic strategies have been pursued which act on different mechanisms of mitochondrial dysfunction, but clinical trials are warranted to improve the management of MD patients.
\end{abstract}

Keywords: Mitochondrial diseases, dystonia, tremor, parkinsonism, myoclonus, basal ganglia, mtDNA mutations, multiple deletions

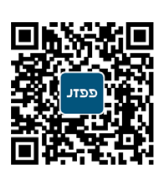




\section{INTRODUCTION}

Mitochondrial diseases (MD) are the most common inherited metabolic disorders due to mitochondrial dysfunction $^{[1]}$.

Mitochondria harbor their own DNA (mtDNA), which is a 16.6-kb double-stranded circular DNA encoding for 13 subunits of respiratory chain (RC), whereas the nuclear DNA (nDNA) identifies about 79 subunits of $\mathrm{RC}$ and several other proteins involved in the synthesis of cofactors (e.g., iron-sulfur proteins, hemes, and copper) as well as in the assembly of the five RC complexes.

In $\mathrm{MD}$, the structure and function of mitochondria are impaired due to mutations in genes encoded by mtDNA or nDNA; for this reason, the genetics of MD is quite complex and in continuous evolution ${ }^{[2]}$. A genetic classification of MD distinguishes two main categories: (1) MD caused by primary mtDNA mutations; and (2) MD due to mutations in several nDNA genes, related to mitochondria. Defects involving these nuclear genes can be divided into five subcategories: (1) genes encoding subunits of the five complexes of respiratory chain; (2) genes encoding assembly factors of the complexes; (3) genes responsible for mtDNA maintenance (replication, maintenance of nucleotide pools, and mtDNA quality control); (4) genes encoding for biosynthetic enzymes for lipids, amino acids, and cofactors; and (5) genes encoding for other proteins that influence secondarily oxidative phosphorylation.

The oxidative phosphorylation (OXPHOS) dysfunction results in an impairment of oxidative energy metabolism, with defective utilization of nutrients to generate energy (ATP), thereby causing an accumulation of metabolic intermediates, increased oxidative stress, and decreased energy production. Consequently, tissues highly energy-dependent such as skeletal muscle, central and peripheral nervous system, heart, and liver can be affected by the bioenergetics deficiency in the same individual, explaining the multi-organ failure that is typical of these disorders.

MD may appear at any age with a wide clinical spectrum, although some clinical syndromes have typical infantile onset, whereas others occur later and usually have a milder course ${ }^{[3]}$.

The nervous system and skeletal muscle, because of their high-energy dependence and susceptibility, are invariably involved in most MD. Neurological features include epilepsy, psychomotor retardation, migraine, stroke-like episodes, dementia, peripheral neuropathy, and sensitive and cerebellar ataxia ${ }^{[4]}$. Movement disorders $(\mathrm{MoD})$ are defined as neurological features due to dysfunction of basal ganglia and their connections and are common in $\mathrm{MD}$, as either hyper- or hypokinetic form ${ }^{[5]}$. Among them, dystonia, parkinsonism, myoclonus, tremor, and chorea are more frequently reported ${ }^{[6,7]}$. In pediatric MD patients, dystonia and chorea are often reported, whereas parkinsonism is commonly described in adults ${ }^{[8]}$.

Clinical presentation of movement disorders is variable; some studies report on the occurrence of either a single type of extrapyramidal sign or a combination of two or more MoD in the same patient, usually in the context of a multisystem disorder but rarely as an isolated manifestation of $\mathrm{MD}^{[7-9]}$.

Diagnosis of MD is quite challenging because of the variability of the clinical presentation as well as the presence of symptoms overlapping with other neuromuscular or neurodegenerative disorders; however, recurrent clinical findings usually in classical syndromes associated with specific mtDNA mutations strongly suggest the diagnosis. Laboratory investigations can help to addressed the diagnosis, being the main findings that lead to the diagnosis: elevated lactate levels; the presence of some morphological findings on muscle biopsy as "ragged red fibers (RRF)" on Gomori trichrome stain and/or cytochrome oxidase negative fibers (COX-ve fibers); detection of defect of mitochondrial respiratory chain enzyme activities or CoQ levels; and the identification of pathogenic mutations in either mtDNA or nDNA. 
Table 1. Main studies reporting on frequency of movement disorders associated with mitochondrial diseases

\begin{tabular}{|c|c|c|c|c|}
\hline Author & $\begin{array}{c}\text { Patients } \\
\text { cohort }\end{array}$ & $\begin{array}{l}\text { No. of MD patients } \\
\text { with MoD (\%) }\end{array}$ & $\begin{array}{c}\text { Spectrum of movement disorders } \\
\text { No. of MD patients (\%) }\end{array}$ & $\begin{array}{l}\text { Neuroradiological } \\
\text { findings }\end{array}$ \\
\hline SchregImann et al. ${ }^{[14]} 2018$ & $\begin{array}{l}50 \text { pts with } \\
\mathrm{MD}^{1}\end{array}$ & $15(30 \%)$ & $\begin{array}{l}5(10 \%) \text { dystonia; } 3(6 \%) \text { parkinsonism; } \\
2(4 \%) \text { myoclonus, } 2(4 \%) \text { chorea; } 3 \\
(6 \%) \text { ataxia }\end{array}$ & $\begin{array}{l}\text { Brain MRI showed } \\
\text { cerebellar atrophy mainly } \\
\text { lobule VI and VII in all } \\
\text { MD pts. with MoD }\end{array}$ \\
\hline Martikainen et al. ${ }^{[8]} 2016$ & $\begin{array}{l}678 \text { pts with } \\
M^{1} \\
(87 \% \text { adults })\end{array}$ & $\begin{array}{l}42(6.1 \%): 12 \text { pediatric } \\
\text { pts and } \\
30 \text { adults }\end{array}$ & $\begin{array}{l}\text { 11/12 (92\%) dystonia } \\
13 / 30(43 \%) \text { parkinsonism } \\
\text { 11/30 (37\%) multifocal or generalized } \\
\text { dystonia in mtDNA mutations }\end{array}$ & $\begin{array}{l}\text { Brain MRI revealed } \\
\text { symmetric basal ganglia } \\
\text { lesions (putamen and } \\
\text { globus pallidus), in } 16 \\
\text { pts; cerebellar atrophy in } \\
6 \text { pts } \\
\text { No calcifications were } \\
\text { detected } \\
\text { DAT-SPECT abnormal in } \\
\text { 9/12 pts }\end{array}$ \\
\hline Mancuso et al. ${ }^{[90]} 2014$ & $\begin{array}{l}1086 \text { pts with } \\
\mathrm{MD}^{1}\end{array}$ & $39(3.6 \%)$ & $\begin{array}{l}39(3.6 \%) \text { myoclonus (study focused } \\
\text { only on myoclonus) }\end{array}$ & $\begin{array}{l}\text { Brain MRI showed } \\
\text { variably cortical/ } \\
\text { subcortical atrophy, } \\
\text { white matter } \\
\text { abnormalities, cerebellar } \\
\text { atrophy }\end{array}$ \\
\hline Sofou et al. ${ }^{[20]} 2014$ & $\begin{array}{l}130 \text { children } \\
\text { with LS ( } 73 \\
\text { genetically } \\
\text { defined) }\end{array}$ & - & $\begin{array}{l}58(44 \%) \text { dystonia } \\
45(34 \%) \text { ataxia } \\
27(20 \%) \text { other dyskinesias } \\
25(19 \%) \text { chorea/athetosis } \\
9(7 \%) \text { myoclonus }\end{array}$ & n.r. \\
\hline $\begin{array}{l}\text { Piekutowska-Abramczuk et al. }{ }^{[23]} \\
2009\end{array}$ & 41 pts with $\mathrm{LS}^{1}$ & $31(75 \%)$ & $\begin{array}{l}17(41 \%) \text { tremor } \\
14(34 \%) \text { dystonic movements, ataxia, } \\
\text { extrapyramidal syndrome }\end{array}$ & n.r. \\
\hline Zhang et al. ${ }^{[21]} 2007$ & $\begin{array}{l}124 \text { pts with } \\
\text { LS, LLS ( } 26 \% \\
\text { genetically } \\
\text { defined) }\end{array}$ & $12(10 \%)$ & $12(10 \%)$ dystonia & n.r. \\
\hline Finsterer et al. ${ }^{[50]} 2002$ & 76 pts with $\mathrm{MD}^{1}$ & $9(12 \%)$ & $\begin{array}{l}9(12 \%) \text { parkinsonism (study focused } \\
\text { only on parkinsonism) }\end{array}$ & n.r. \\
\hline Macaya et al. ${ }^{[12]} 1993$ & 34 pts with LS & $22(65 \%)$ & $\begin{array}{l}19(86 \%) \text { dystonia } \\
4(18 \%) \text { rigidity } \\
2(9 \%) \text { tremor } \\
2(9 \%) \text { chorea }\end{array}$ & n.r. \\
\hline
\end{tabular}

${ }^{1}$ All patients genetically defined. MD: mitochondrial disorders; LLS: Leigh-like syndrome; MoD: movement disorders; LS: Leigh syndrome; n.r.: not reported

The frequency of MoD in MD patients has only been reported in single-center studies, from small series of patients, and for specific forms of $\mathrm{MD}^{[8-14]}$. Few population-based, cross-sectional studies have assessed the clinical and genetic characteristics of $\mathrm{MoD}$ in large $\mathrm{MD}$ cohorts [Table 1].

In the present review, we highlight the clinical spectrum of $\mathrm{MoD}$ in mitochondrial encephalomyopathies, discussing separately each movement disorder which has been reported in the literature in MD patients with $\mathrm{MoD}$, carrying either mtDNA or nuclear genes mutations. We focus on dystonia and parkinsonism with some recent developments on the pathophysiological mechanisms of extrapyramidal features in MD and their management.

\section{DYSTONIA}

Dystonia is a neurological movement disorder characterized by sustained or prolonged muscle contractions that result in twisting and repetitive movements or abnormal fixed postures ${ }^{[15]}$. According to body distribution, it is classified as generalized, focal, or segmental. The genetics of dystonia is quite complex and several genes have been discovered, although the genetic underpinnings of several adult onset forms are still undefined ${ }^{[16]}$.

An international expert panel classified three main types of dystonia: isolated dystonia that is referred to as primary dystonia; combined dystonia when additional movement disorders are present; and complex dystonia, 
Table 2. Main mtDNA mutations associated with dystonia and chorea

\begin{tabular}{|c|c|c|c|c|}
\hline Gene & Mutation & Clinical features & Other clinical features & Ref. \\
\hline$\overline{M t D N A}$ & $\begin{array}{l}\text { Large single } \\
\text { deletion }\end{array}$ & Segmental dystonia & KSS & Marie et al. ${ }^{[42]}, 1999$ \\
\hline MT-TL1 & m.3243G > A & $\begin{array}{l}\text { Writer's cramp } \\
\text { Choreic movements }\end{array}$ & $\begin{array}{l}\text { MELAS } \\
\text { MELAS }\end{array}$ & $\begin{array}{l}\text { Sudarsky et al. }{ }^{[43]}, 1999 \\
\text { Nakagaki et al. }{ }^{[4]}, 2005, \text { Kang et al. }{ }^{[48]}, 2005\end{array}$ \\
\hline MT-TK & $\begin{array}{l}\mathrm{m} .3251 \mathrm{G}>\mathrm{A} \\
\mathrm{m} .8344 \mathrm{G}>\mathrm{A}\end{array}$ & $\begin{array}{l}\text { Chorea-ballism } \\
\text { Spasmodic dysphonia }\end{array}$ & $\begin{array}{l}\text { MELAS } \\
\text { MERRF }\end{array}$ & $\begin{array}{l}\text { Lahiri et al. } .^{[49]}, 2019 \\
\text { Peng et al. }{ }^{[44]}, 2003\end{array}$ \\
\hline MT-ATPG & m.9176T >C & Generalized dystonia/chorea & LS & Martikainen et al. ${ }^{[8]}, 2016$ \\
\hline MT-ND1 & $\begin{array}{l}\text { m.3460G }>A \\
\text { m.3796G }>A\end{array}$ & $\begin{array}{l}\text { Dystonia } \\
\text { Adult onset dystonia }\end{array}$ & $\begin{array}{l}\text { LHON } \\
\text { Spasticity, and core-type myopathy. }\end{array}$ & $\begin{array}{l}\text { Meire et al. }{ }^{[37]}, 1995 \\
\text { Simon et al. }{ }^{[39]}, 2003\end{array}$ \\
\hline MT-ND3 & m.10197G $>$ A & Dystonia & $\begin{array}{l}\text { LS/LLS, vertebral and arterial malformations } \\
\text { LHON }\end{array}$ & $\begin{array}{l}\text { Tolomeo et al. }{ }^{[24]}, 2019 \\
\text { Wang et al. }{ }^{[26]}, 2009\end{array}$ \\
\hline MT-ND4 & $\mathrm{m} .11178 \mathrm{G}>\mathrm{A}$ & $\begin{array}{l}\text { Dystonia } \\
\text { Chorea }\end{array}$ & $\begin{array}{l}\text { LHON } \\
\text { LHON }\end{array}$ & $\begin{array}{l}\text { Nikoskelainen et al. }{ }^{[38]}, 1995 \\
\text { Morimoto et al. }{ }^{[46]}, 2004\end{array}$ \\
\hline MT-NDG & $\begin{array}{l}\mathrm{m} .14459 \mathrm{G}>\mathrm{A} \\
\mathrm{m} .14487 \mathrm{~T}>\mathrm{C}\end{array}$ & $\begin{array}{l}\text { Dystonia } \\
\text { Generalized dystonia }\end{array}$ & $\begin{array}{l}\text { LHON } \\
\text { LS }\end{array}$ & $\begin{array}{l}\text { Gropman et al. }{ }^{[27]}, 2004 \\
\text { Ugalde et al. }{ }^{[25]}, 2003\end{array}$ \\
\hline
\end{tabular}

KSS: Kearns-Sayre syndrome; MELAS: mitochondrial encephalomyopathy and lactic acidosis and stroke-like episodes; LHON: Leber hereditary optic neuropathy; MERRF: mitochondrial encephalomyopathy with ragged red fibers

Table 3. Selected nDNA mitochondrial-related genes associated with dystonia and chorea

\begin{tabular}{|c|c|c|c|c|}
\hline Gene & $\begin{array}{l}\text { Defect on mitochondrial } \\
\text { function }\end{array}$ & MoD clinical features & Other clinical features & Ref. \\
\hline$\overline{S U R F 1}$ & Complex IV assembly & Dystonia, ataxia, athetoid movements & $\begin{array}{l}\text { Developmental delay, } \\
\text { ophthalmoplegia, feeding } \\
\text { problems }\end{array}$ & Wedatilake et al. ${ }^{[29]}, 2013$ \\
\hline NDUFAFG & Complex I assembly & Dystonia with childhood onset & LS & Baide-Mairena et al. ${ }^{[30]}, 2019$ \\
\hline SUCLA2 & mtDNA depletion & Dystonia/Chorea & LS & Carrozzo et al. ${ }^{[31]}, 2007$ \\
\hline ATAD3 & mtDNA depletion & Dystonia & $\begin{array}{l}\text { Encephalopathy with } \\
\text { cerebellar atrophy }\end{array}$ & Desai et al. ${ }^{[32]}, 2017$ \\
\hline MTFMT & Combined ox-phos deficiency & Multifocal dystonia with childhood onset & LS & Martikainen et al. ${ }^{[8]}, 2016$ \\
\hline FARS2 & Combined ox-phos deficiency & Generalized dystonia with childhood onset & Seizures, learning disability & Martikainen et al. ${ }^{[8]}, 2016$ \\
\hline PDHX & PDH deficiency & Generalized dystonia with childhood onset & $\begin{array}{l}\text { Seizures, learning disability, } \\
\text { deafness }\end{array}$ & Martikainen et al. ${ }^{[8]}, 2016$ \\
\hline TIMM8a & $\begin{array}{l}\text { Defect of mitochondrial } \\
\text { protein import }\end{array}$ & Dystonia with childhood onset & $\begin{array}{l}\text { Early deafness, optic } \\
\text { neuronopathy }\end{array}$ & Aguirre et al. ${ }^{[36]}, 2006$ \\
\hline SERAC1 & $\begin{array}{l}\text { Defect of ox-phos and } \\
\text { cholesterol trafficking }\end{array}$ & Dystonia with infantile onset & $\begin{array}{l}\text { 3-Methylglutaconic aciduria, } \\
\text { deafness, hepatopathy, Leigh- } \\
\text { like syndrome (MEGDHEL) }\end{array}$ & Maas et al. ${ }^{[33]}, 2017$ \\
\hline MECR & $\begin{array}{l}\text { Defect of ox-phos and } \\
\text { cholesterol trafficking }\end{array}$ & Dystonia with childhood onset & & Heimer et al. ${ }^{[34]}, 2016$ \\
\hline POLG1 & mtDNA replication & $\begin{array}{l}\text { Torticollis, focal eyelid dystonia, and limb } \\
\text { dystonia with adult onset }\end{array}$ & $\begin{array}{l}\text { Ataxia, seizures, neuropathy, } \\
\text { PEO }\end{array}$ & Hinnell et al. ${ }^{[45]}, 2012$ \\
\hline
\end{tabular}

LS: Leigh syndrome; ox-phos: oxidative phosphorylation; PDH: pyruvate dehydrogenase; PEO: progressive external ophthalmoplegia

referring to secondary forms when it occurs in the context of a complex phenotype ${ }^{[17]}$. In the majority of MD cases, we are faced with complex dystonia type.

Dystonia has been described both in mtDNA mutations and in several nuclear genes related to mitochondria [Tables 2 and 3].

\section{Dystonia in pediatric MD}

Dystonia is the most common movement disorder in the pediatric population with $\mathrm{MD}$, mainly in the context of a Leigh syndrome $(\mathrm{LS})^{[8]}$.

LS is a devastating disorder, occurring in infants or children characterized by a severe encephalopathy with bilateral basal ganglia lesions in whom dystonia is part of a complex phenotype including developmental delay, hypotonia, ataxia, optic atrophy, and seizures. This syndrome is genetically quite heterogeneous and several genes, either mitochondrial or nuclear, have been involved. Leigh-like syndrome (LLS) is considered a variant of LS when features suggest a Leigh syndrome but some atypical clinical and neuroimaging are present. 
A recent meta-analysis including five studies with 385 Leigh syndrome patients showed that $32 \%$ of the patients carried mtDNA mutations, whereas $38 \%$ had nDNA mutations ${ }^{[18]}$.

In a retrospective study on 34 patients with LS, dystonia was found in 59\% and was present usually as generalized or multifocal form ${ }^{[19]}$. In other studies, the recurrence was variable usually because of the retrospective nature of the studies and also the small number of patients included ${ }^{[20-23]}$.

Different mtDNA mutations are reported in patients with dystonia and LS or LLS including mainly mtDNA encoded complex subunits such as ATP6, ND3, or ND6 ${ }^{[8,24,25]}$.

Interestingly, the $10197 \mathrm{G}>\mathrm{A}$ in ND3 shows a quite variable phenotype ranging from LS to LHON. Recently, a review of published data on patients harboring the m.10197G > A mutation showed that $38 \%$ of patients had a stable dystonia associated with ataxia, seizures, and dysarthria. The same mutation was also described in a single large family with LHON and dystonia ${ }^{[26]}$. Neuroimaging findings were consistent with LS. Dystonic postures appeared early and sometimes had a remitting-relapsing course ${ }^{[24]}$.

The m.14459G > A mutation in ND6 has been described in pediatric patients with generalized dystonia (also named as DYT-mt-ND6) with heterogeneous clinical manifestations, ranging from isolated dystonia with no cognitive involvement to encephalopathy with dystonia, dysphagia, pyramidal tracts dysfunction, and cognitive impairment ${ }^{[27]}$.

Variants in several nDNA genes are reported in patients with $\mathrm{LS}^{[28]}$. We can distinguish nuclear genes encoding OXPHOS enzymes and their assembly factors, defects of mitochondrial DNA maintenance and translation, mitochondrial membrane lipid remodeling, and pyruvate dehydrogenase.

Among LS patients due to nDNA genes, SURF1 gene is one of the most frequently involved genes. SURF1 is a cytochrome $\mathrm{c}$ assembly factor and related mutations cause an isolated complex IV deficiency. Clinical symptoms begin in late infancy with gastro-intestinal symptoms, developmental delay, ophthalmoplegia, ataxia, seizures, dystonia, and respiratory failure ${ }^{[29]}$.

Recently, a mutation in NDUFAF6, a complex I assembly factor, has been described in three siblings with childhood onset dystonia associated with bilateral striatal necrosis, neurological regression, and long survival $^{[30]}$.

Among mtDNA depletion syndromes, mutations in SUCLA2 gene, leading to succinyl-CoA synthase deficiency, have been reported in patients with neonatal onset encephalomyopathy, deafness, dystonia, and MRI abnormalities of putamen and caudate nuclei. As another nuclear gene causing mtDNA depletion, $A T A D 3$ gene has been associated with a severe encephalopathy with generalized dystonia, ataxia, and brainstem and cerebellar hypoplasia ${ }^{[31]}$.

Mutations of MECR or SERAC1, genes involved in the mitochondrial lipid metabolism and transport, are associated with severe Leigh-like syndromes with early onset dystonia ${ }^{[32,33]}$.

Dystonia with childhood onset has been reported in complex phenotypes causing by combined oxidative phosphorylation deficiencies due to different mitochondrial genes, such as MTFMT and FARS2 involved in mtDNA translation ${ }^{[8]}$.

Of interest is a well-defined syndrome characterized by deafness, dystonia, and optic neuropathy previously called Mohr-Tranebjaerg syndrome (MTS) due to mutations in TIMM8A. The gene is located on 
chromosome $\mathrm{X}$ and encodes for a protein (deafness dystonia protein 1) located in the inner mitochondrial membrane and implicated in the mitochondrial protein transport system ${ }^{[34,35]}$. Dystonia is the second major feature of MTS and is usually generalized, affecting more cranio-cervical muscles, and slowly progressive. Age of onset is significantly variable, ranging from the first to the fourth decade. Interestingly, adult-onset focal dystonia (torticollis and writer's cramp) with no evidence of hearing impairment has been reported in female carriers ${ }^{[35]}$. Brain MRI in this condition do not show the basal ganglia lesions that are usually evident in the majority of MD patients with dystonia.

\section{Dystonia in MD adults}

Dystonia is a MoD reported also in adult MD cases. The association of Leber hereditary optic neuropathy (LHON) with variable combination of progressive generalized dystonia and visual loss is well known, and is occasionally accompanied by pyramidal tract signs and intellectual impairment ${ }^{[36]}$. Dystonia can precede ocular abnormalities by several years. LHON is due to homoplasmic mtDNA mutations in MT-ND1, MTND4, and MT-ND6; the three primary mutations are m.3460G > A, m.11778G > A, and m.14484T > C, which are all described in combination with generalized dystonia ${ }^{[37,38]}$. Less common mutations in different mtDNA ND genes are described in patients with generalized dystonia ${ }^{[39,40]}$. In the presence of dystonia, brain MRI shows frequently bilateral putamen and caudate nuclei lesions that have rarely been described in patients carrying MT-ND6 mutations without dystonia ${ }^{[41]}$.

Dystonia has sporadically been reported in some classical mtDNA-related syndromes such as Kearns-Sayre Syndrome (KSS), a sporadic condition due to large single deletions and characterized by progressive external ophthalmoplegia, cardiac conduction block, and pigmentary retinal degeneration in combination with other symptoms, e.g., ataxia, dystonia, and extraneurological signs ${ }^{[42]}$. Focal dystonia has been described in single case reports of MELAS (mitochondrial encephalomyopathy with stroke-like episodes) and MERRF (myoclonus epilepsy with ragged-red fibers ${ }^{[43,44]}$.

Dystonia is also rarely reported in MD patients harboring mutations in POLG (mitochondrial DNA polymerase $\gamma$ ), which is considered one of the most mutated nuclear genes in MD and is associated with a very heterogeneous phenotype characterized by progressive external ophthalmoplegia, myoclonic epilepsy, parkinsonism, and ataxia. In some POLG cases, the phenotype also includes cervical dystonia, focal eyelid dystonia, and limb dystonia but not as a prominent feature ${ }^{[45]}$.

\section{CHOREA/CHOREOATETOSIS}

Choreic or choreathetotic movements have been described in children with LS. In the study by Martikainen et al. ${ }^{[8]}$, 6/42 MD patients with movement disorders (14\%) presented with chorea or complex hyperkinetic movement disorders.

Choreic movements are rarely reported in adult-onset MD. Among mtDNA mutations, chorea has been described in a single case associated with the G11778A mutation. The patient presented at age 24 with involuntary movements that initially involved both hands and further became generalized; by the age of 37, she also developed severe dementia ${ }^{[46]}$. Few MELAS cases are described with acute-onset chorea often triggered by hyperglycemia ${ }^{[47-49]}$.

\section{PARKINSONISM}

Parkinsonism is the most frequent hypokinetic disorder in adult MD patients. It has been associated with mtDNA and nDNA gene variants ${ }^{[50]}$. In a study focused on the evaluation of cardinal features of parkinsonism such as bradykinesia, tremor, and rigidity, the prevalence of parkinsonism was calculated at $12 \%{ }^{[51]}$; although a possible incidental association was supposed, the complexity of the phenotype does not support this concern. 
Table 4. Parkinsonism associated with mtDNA mutations

\begin{tabular}{|c|c|c|c|c|}
\hline Gene & Mutation & Clinical features of parkinsonism & Other clinical features & Ref. \\
\hline MtDNA & Large single deletions & Asymmetrical or symmetrical parkinsonism & PEO & SchregImann et al. ${ }^{[14]}, 2018$ \\
\hline \multirow[t]{2}{*}{ MT-ND4 } & $m .11778 G>A$ & Asymmetrical akinesia, rigidity & LHON & Vital et al. ${ }^{[58]}, 2015$ \\
\hline & & Bilateral akinesia, rigidity & LHON & Simon et al. ${ }^{[57]}, 1999$ \\
\hline MT-TI & $m .4296 G>A$ & Bilateral akinesia, rigidity & LS, hypogonadism & Martikainen et al. ${ }^{[54]}, 2013$ \\
\hline MT-TK & $m .8344 A>G$ & Asymmetrical akinesia, rigidity, tremor & MERRF & Horvath et al. ${ }^{[53]}, 2007$ \\
\hline MT-RNR1 & $\mathrm{m} .1095 \mathrm{~T}>\mathrm{C}$ & Hemiparkinsonism with akinesia, rigidity, tremor & Hypoacusia, neuropathy & Thyagarajan et al. ${ }^{[52]}, 2000$ \\
\hline$M T-C Y B$ & 4 bp deletion & Symmetrical akinesia, rigidity, tremor & Stroke-like episodes & De Coo et al. ${ }^{[55]}, 1999$ \\
\hline
\end{tabular}

PEO: progressive external ophthalmoplegia; LHON: Leber hereditary optic neuropathy; MERRF: mitochondrial encephalomyopathy with ragged red fibers

The majority of reports describing a Parkinson-like phenotype in the context of a mitochondrial syndrome are associated with mutation in nDNA genes but more rarely extrapyramidal features have been described in few cases of mtDNA-related syndromes, such as MERRF, MELAS, and LHON ${ }^{[52-54]}$. De Coo et al ${ }^{[55]}$ reported on a patient with a MELAS-like syndrome with parkinsonism due to a 4-bp deletion in the mitochondrial cytochrome B gene (MTCYB) ${ }^{[5,56]}$. Similarly, bradykinesia and rigidity were reported in LHON cases with mutation in ND4 gene ${ }^{[57,58]}$. The main reports on mtDNA mutations associated with parkinsonism are summarized in Table 4.

Recent studies have demonstrated that the nigrostriatal system is very vulnerable to mitochondrial dysfunction $^{[59]}$, and conditions characterized by an impairment of mtDNA maintenance and consequently accumulation of somatic mtDNA damage are frequently associated with a nigrostriatal degeneration with or without clinical signs of parkinsonism ${ }^{[14]}$. In the last two decades, several reports have described MD cases with a complicated phenotype, including parkinsonian features such as akinesia, resting tremor, and rigidity due to mutations in nuclear genes involved in mtDNA maintenance such as POLG, TWNK ${ }^{[00,61]}$, and, more rarely, OPA1, MPV17, and POLG2 ${ }^{[62-64]}$. POLG1-related syndromes are the most common forms, either dominant or recessive, associated with levodopa responsive parkinsonism with a variable onset of the parkinsonism from early to advanced age ${ }^{[65-73]}$. Nevertheless, parkinsonism has been reported in few pathogenic TWNK mutations. TWNK (named also C10orf2) is a gene encoding the Twinkle protein, an adenine nucleotide-dependent DNA helicase that is involved in the maintenance of mtDNA integrity.

Patients showed an asymmetrical parkinsonism with progressive external ophtalmoplegia (PEO) and myopathy and a wide range of disease onset from juvenile to adult forms ${ }^{[74-77]}$.

In recent years, it has been demonstrated that genes involved in mitochondrial dynamics have impaired mtDNA maintenance; among them, mutations in OPA1, but also in AFG3L2 and SPG7, have been related to nigrostriatal dysfunction. Some years ago, we described two unrelated families harboring a heterozygous dominant OPA 1 mutation with a clinical picture characterized by PEO, parkinsonism, cognitive impairment, and nigrostriatal dysfunction at DAT-SCAN. Functional studies revealed an imbalance of autophagy and mitophagy $^{[62]}$.

Recently, among 35 SPG7 patients, parkinsonism was observed in $21 \%$ of cases. mtDNA copy number quantification in blood revealed significantly lower mtDNA levels in either patients or carriers than controls ${ }^{[78]}$.

An overview of clinical, genetic, and neuroradiological findings in MD cases with parkinsonism due to mitochondrial-related nDNA genes reported in the literature is summarized in Table $5^{[79-84]}$.

Clinical presentation of mitochondrial parkinsonism (MP) seems not different from idiopathic Parkinson disease and for this reason MP can be overlooked. For instance, parkinsonism related to POLG mutations 
Table 5. Parkinsonism associated with mutations in mitochondrial-related nDNA genes

\begin{tabular}{|c|c|c|c|c|c|}
\hline Gene & Mutation & $\begin{array}{l}\text { Protein } \\
\text { change }\end{array}$ & $\begin{array}{l}\text { Clinical features of } \\
\text { parkinsonism }\end{array}$ & Other clinical aspects & Ref. \\
\hline \multirow[t]{10}{*}{$P O L G$} & $\begin{array}{l}\text { c. } 2693 T>C \\
\text { c. } 2993 C>T\end{array}$ & $\begin{array}{l}\text { I898T } \\
\text { S998L }\end{array}$ & Early onset rigidity, akinesia & PEO, optic atrophy & Ma et al. ${ }^{[84]} 2019$ \\
\hline & $\begin{array}{l}\text { c. } 830 A>T \\
\text { c. } 2827 C>T\end{array}$ & $\begin{array}{l}\text { H277L } \\
\text { R943C }\end{array}$ & $\begin{array}{l}\text { Asymmetrical akinesia, } \\
\text { rigidity }\end{array}$ & PEO & Sato et al. ${ }^{[73]} 2011$ \\
\hline & c. $2864 \mathrm{~A}>\mathrm{G}$ & Y955C & $\begin{array}{l}\text { Bilateral akinesia, rigidity } \\
\text { Asymmetrical tremor }\end{array}$ & $\begin{array}{l}\text { PEO, myopathy } \\
\text { PEO, myopathy, neuropathy, } \\
\text { hypogonadism }\end{array}$ & Synofzik et al. ${ }^{[71]} 2010$ \\
\hline & $\begin{array}{l}\text { c. } 3311 C>G \\
\text { c. } 2542 G>A\end{array}$ & G848S & Akinesia, rigidity, tremor & PEO, myopathy & Betts-Henderson et al. ${ }^{[67]} 2009$ \\
\hline & $\begin{array}{l}\text { c. } 1288 \mathrm{~A}>\mathrm{T} \\
\text { c. } 2752 \mathrm{~T}>\mathrm{C}\end{array}$ & $\begin{array}{l}\text { M430L } \\
\text { W918L }\end{array}$ & Bilateral tremor, rigidity & PEO, myopathy & Invernizzi et al. ${ }^{[68]} 2008$ \\
\hline & c. $2243 G>C$ & W748S & $\begin{array}{l}\text { Bilateral akinesia, rigidity, } \\
\text { tremor }\end{array}$ & $\begin{array}{l}\text { PEO, sensory and cerebellar } \\
\text { ataxia }\end{array}$ & Remes et al. ${ }^{[69]} 2008$ \\
\hline & $\begin{array}{l}\text { c. } 1389 \mathrm{G}>\mathrm{T} \\
\text { c. } 1532 \mathrm{G}>\mathrm{A}\end{array}$ & S511N & Bilateral akinesia, rigidity & PEO, myopathy, neuropathy & Hudson et al. ${ }^{[70]} 2007$ \\
\hline & $\begin{array}{l}\text { c. } 2839 C>T \\
\text { c. } 2491 G>C\end{array}$ & $\begin{array}{l}\text { R853N } \\
\text { G737R }\end{array}$ & Bilateral akinesia, rigidity & PEO, myopathy, dystonia & Davidzon et al. ${ }^{[66]} 2006$ \\
\hline & c. $2492 A>G$ & Y831C & $\begin{array}{l}\text { Symmetrical akinesia, rigidity, } \\
\text { tremor }\end{array}$ & PEO, myopathy & Mancuso M et al. ${ }^{[65]} 2004$ \\
\hline & $\begin{array}{l}\text { c. } 2864 A>G \\
\text { c. } 1402 A>G \\
\text { c. } 313 G>A\end{array}$ & $\begin{array}{l}\text { Y955C } \\
\text { N468D }\end{array}$ & Tremor and/or akinesia, rigidity & PEO & Luoma et al. $2004^{[60]} 2004$ \\
\hline $\begin{array}{l}\text { ANT1 } \\
\text { POLG }\end{array}$ & $\begin{array}{l}\text { c. } 865 G>A \\
\text { c. } 1399 G>A\end{array}$ & A467T & Bilateral akinesia, rigidity & PEO, myopathy, neuropathy & Galassi et al. ${ }^{[72]} 2008$ \\
\hline \multirow[t]{2}{*}{ POLG2 } & c. $970-1 G>C$ & - & $\begin{array}{l}\text { Asymmetrical tremor and } \\
\text { bradykinesia }\end{array}$ & $\begin{array}{l}\text { Sensory and cerebellar ataxia, } \\
\text { dementia, PEO }\end{array}$ & Van Maldergem et al. ${ }^{[64]} 2016$ \\
\hline & c.1192-8_1207dup24 & - & Camptocormia & & Lehmann Urban et al. ${ }^{[83]} 2020$ \\
\hline \multirow[t]{4}{*}{ TWNK } & c. $907 \mathrm{C}>\mathrm{T}$ & R3030W & $\begin{array}{l}\text { Asymmetrical tremor and } \\
\text { akinesia, rigidity }\end{array}$ & PEO, myopathy & Brandon et al. ${ }^{[77]} 2013$ \\
\hline & c.1750G > A & A359T & $\begin{array}{l}\text { Asymmetrical tremor and } \\
\text { akinesia, rigidity }\end{array}$ & PEO, neuropathy & Kiferle et al. ${ }^{[76]} 2013$ \\
\hline & c. $1031 G>A$ & R334Q & $\begin{array}{l}\text { Asymmetrical tremor, akinesia, } \\
\text { rigidity }\end{array}$ & PEO, neuropathy & Vandenberghe et al. ${ }^{[75]} 2009$ \\
\hline & c. $1121 \mathrm{G}>\mathrm{A}$ & R374Q & $\begin{array}{l}\text { Asymmetrical akinesia, rigidity, } \\
\text { tremor }\end{array}$ & PEO & Baloh et al. ${ }^{[61]} 2007$ \\
\hline OPA1 & $\begin{array}{l}\text { c. } 1462 \mathrm{G}>\mathrm{A} \\
\text { c. } 1484 \mathrm{C}>\mathrm{T}\end{array}$ & $\begin{array}{l}\text { G488R } \\
\text { A495V }\end{array}$ & Akinesia, rigidity, tremor & $\begin{array}{l}\text { PEO, myopathy, neuropathy, } \\
\text { dementia }\end{array}$ & Carelli et al. ${ }^{[62]} 2015$ \\
\hline MPV17 & $\begin{array}{l}\text { c. } 428 \mathrm{~T}>\mathrm{G} \\
\text { c. } 263 \mathrm{~A}>\mathrm{T} \\
\text { c. } 265 \mathrm{~A}>\mathrm{T}\end{array}$ & $\begin{array}{l}\text { L143* } \\
\text { K88M } \\
\text { M89L }\end{array}$ & Akinesia, rigidity, tremor & PEO, myopathy, neuropathy & Garone et al. ${ }^{[63]} 2012$ \\
\hline$S P G 7$ & c. 1529 C > T & A510V & $\begin{array}{l}\text { bradykinesia, rest tremor, and } \\
\text { rigidity }\end{array}$ & Ataxia, PEO & De la Casa-Fages et al. ${ }^{[78]} 2019$ \\
\hline n.a. & mtDNA MDels & - & Tremor, moderate bradykinesia & PEO, neuropathy & Wilcox et al. ${ }^{[79]} 2007$ \\
\hline n.a. & mtDNA MDels & - & $\begin{array}{l}\text { Asymmetrical akinesia, rigidity, } \\
\text { rest tremor }\end{array}$ & - & Siciliano et al. ${ }^{[81]} 2001$ \\
\hline n.a. & mtDNA MDels & - & Asymmetrical akinesia, rigidity & PEO, myopathy & Casali et al. ${ }^{[82]} 2001$ \\
\hline n.a. & mtDNA MDels & - & $\begin{array}{l}\text { asymmetric rest tremor } \\
\text { akinesia, rigidity }\end{array}$ & PEO, myopathy, neuropathy & Chalmers et al. ${ }^{[80]} 1996$ \\
\hline
\end{tabular}

PEO: progressive external ophthalmoplegia; mtDNA MDels: mitochondrial DNA multiple deletions; n.a.: not available

can mimic very well an idiopathic Parkinson disease (IPD) because age of onset, the asymmetric distribution of motor symptoms, the efficacy of dopaminergic drugs, and the support of the imaging studies showing nigrostriatal dysfunction are not dissimilar in these conditions. Nevertheless, reviewing the MP cases reported thus far, it appears evident that MP may manifest earlier than IPD, and some additional clinical features, rarely reported in IP, are indeed recurrent in MP. In fact, considering the reported cases with MP due to mutations in mitochondrial-related nuclear genes impairing mtDNA maintenance [Table 5], it is quite clear that external ophthalmoplegia is a common feature with frequent association with proximal myopathy and less commonly neuropathy and ataxia.

According to these considerations, MP should be suspected in patients manifesting an akinetic syndrome with PEO and myopathic signs. 
The role of mitochondria in idiopathic and familiar Parkinson has been studied for several years and discussing this issue is beyond the scope of the present review. PD was for a long time considered a nongenetic disorder, but, in the last twenty years, several genes have been associated with familial PD. Many genes associated to familial PD are strictly related to mitochondrial function, and different studies have demonstrated that mitochondrial dysfunction has a major role in the pathogenesis of both sporadic and familial $\mathrm{PD}^{[85,86]}$. For instance, two PD-related proteins, PTEN-induced serine/threonine kinase 1 encoded by PINK1 and E3 ubiquitin ligase Parkin encoded by PRKN, regulate mitochondrial quality control, modulating mitochondrial biogenesis via PGC1alfa. However, it has been shown that LRRK2 interacts with several key regulators of mitochondrial fission/fusion ${ }^{[87]}$. Progress on the pathogenesis of PD led to the development of therapeutic strategies targeting mitochondrial dysfunction in PD. Some agents were evaluated in clinical trials to act on neurodegeneration and disease progression but most of them failed to show any efficacy on $\mathrm{PD}^{[88]}$.

\section{MYOCLONUS}

Myoclonus is a well-known symptom of MD and its presence is traditionally considered in association with MERRF. Myoclonus in MD is due to a cortical involvement, mainly affects face and distal upper extremities, and is classified as focal, multifocal, or generalized ${ }^{[89]}$.

In a study on a large group of mitochondrial patients listed in the database of the "Nation-wide Italian Collaborative Network of Mitochondrial Diseases", we evaluated the relevance of myoclonus. Data analysis revealed that myoclonus is rather infrequent in MD; in fact, it was reported in only $3.6 \%$ of patients (39 of $1,086)^{[90]}$. In 7 of 24 MERRF patients $(29 \%)$, myoclonus was the presenting clinical sign at onset.

Myoclonus has also been described in other classical mitochondrial encephalopathies due to mtDNA mutations, such as MELAS and $\mathrm{LHON}^{[91-93]}$. More rarely, it has been reported in patients with $\mathrm{LS}^{[94]}$. Among MD defects due to nDNA mutations, myoclonus is part of the complex phenotype of Alpers syndrome (hepatocerebral syndrome and mtDNA depletion) and MEMSA (myoclonus epilepsy, myopathy, and sensory ataxia), both associated with mutations in POLG ${ }^{[95,96]}$.

Subcortical myoclonus has also rarely been described in CoQ10 deficiency due ADCK3 mutations in association with dystonia (see in Section Ataxia) ${ }^{[97]}$.

\section{ATAXIA}

Although ataxia is not considered, strictu sensu, a movement disorder, it seems worth considering this clinical feature in the present review because it is one of the main and debilitating symptoms among MD. Pure cerebellar ataxia or spinocerebellar forms but also sensitive ataxia due to a sensory system involvement are reported, sometimes in combination, in MD patients ${ }^{[98]}$.

The genetic spectrum of mitochondrial ataxias is quite heterogeneous: it is encountered in several mtDNA mutations, such as large rearrangements or point mutations, but is included in many variants of different nDNA genes as well.

In the last few years, the development of exome-based technologies increased consistently the number of mitochondrial-related genes recognized as responsible for complex encephalopathies with ataxia, making it difficult to deal with this issue. Moreover, variants in the same gene can be associated with a clinical continuum of heterogeneous syndromes, ranging from infantile to late- onset forms (e.g., POLG-related disorders). 
In this section, we first describe the most common phenotypes associated with mtDNA mutations with early or adult onset, and then we describe the main types of mitochondrial ataxias involving nuclear genes.

Considering primary mtDNA mutations, cerebellar ataxia is part of the phenotypic spectrum of KSS, usually in the context of a quite heterogeneous phenotype including neurological and extraneurological symptoms ${ }^{[99]}$.

Early onset sensory ataxia due to a sensitive axonal neuropathy is a prominent feature of NARP (neuropathy, ataxia, retinitis pigmentosa syndrome), a very severe syndrome characterized also by psychomotor retardation, retinitis pigmentosa, dementia, seizures, ataxia, and proximal weakness and due to point mtDNA mutations in the ATP6 gene, one of the two mitochondrial-encoded subunits of ATPase.

Ataxia is also a common symptom in MERRF syndrome that manifests in juveniles or adults with myoclonus, seizures, muscle weakness, and cognitive decline. MtDNA mutation $8344 \mathrm{~A}>\mathrm{G}$ is the most common genetic variant reported in MERRF and represents about $4 \%$ of all reported mtDNA mutations ${ }^{[100]}$. A review of the clinical phenotype in a large cohort of MERFF patients revealed "myoclonus" was more frequently linked to "ataxia" than to "generalized seizures",[101].

Ataxia occurs in a consistent number of patients with MELAS and is associated with cortical atrophy ${ }^{[102]}$.

Pure cerebellar ataxia is one of the common features in Coenzyme Q10 (CoQ10) deficiency syndromes caused by different defects in biosynthetic cascade of CoQ10. This cofactor has a major role in the electron transport from complexes I and II to complex III in the respiratory chain. CoQ10 deficiency has shown a broad spectrum of clinical manifestations ranging from severe infantile multisystemic disease with nephrotic syndrome and encephalomyopathy to juvenile or adult cerebellar ataxia or even isolated myopathy ${ }^{[103]}$. Several genes involved in the biosynthesis of CoQ10 are known to be responsible for primary CoQ10 deficiency; among them, mutations in PDSS1, PDSS2, COQ2, COQ4, COQ6, COQ7, and COQ9 are associated with different phenotypes. For example, mutations in $\mathrm{COQ} 2$, encoding para-hydroxybenzoatepolyprenyl transferase, a key enzyme in the CoQ10 biosynthetic pathway, are responsible for a multisystemic picture with muscle weakness and myoglobinuria, seizures, mental retardation, spasticity, ataxia, and ophthalmoparesis $^{[104]}$. Brain MRI usually reveals a pure cerebellar atrophy as a prominent feature ${ }^{[105]}$.

Mutations in $A D C K 3$, an ancestral kinase with a regulatory role in ubiquinone biosynthesis, are responsible for the most common autosomal recessive ataxia with CoQ10 deficiency (ARCA2). The main clinical features are exercise intolerance, seizures, and mild cognitive impairment with either childhood or juvenile onset ${ }^{[106]}$. However, some adult onset cases have also been reported with a slowly progressive cerebellar ataxia and no additional features. A prompt diagnosis of these forms is essential because patients greatly benefit from oral CoQ10 supplementation ${ }^{[107]}$.

Different mutations in nDNA genes controlling different mitochondrial pathways, such as TWNK, COX20, OPA1, RR2MB, TTC19, and MSTO1 involved in mtDNA maintenance or POLG responsible of mtDNA replication, or genes encoding some amino acyl tRNA synthetase, involved in mtDNA translation, have been reported in MD patients with cerebellar or sensory ataxia usually as part of a complex phenotype $\mathrm{e}^{[108-116]}$.

A distinctive clinical entity is infantile-onset spinocerebellar ataxia, which is frequently due to mutations in TWNK that encodes the Twinkle mitochondrial protein, a helicase that co-localizes with mtDNA in mitochondrial nucleoids, and causes multiple mtDNA deletions. The main clinical features are onset of ataxia before age of 18 , deafness, epilepsy, and sensory axonal neuropathy ${ }^{[112]}$. 
Recently, a complex phenotype with myopathy, cerebellar atrophy and ataxia, motor developmental delay, and pigmentary retinopathy has been associated with mutations in MSTO1, a cytoplasmic protein required for mitochondrial fusion and network formation ${ }^{[114]}$.

Mutations in POLG1 gene encoding the catalytic subunit of mtDNA polymerase can cause either mtDNA depletion with early childhood syndromes or mtDNA multiple deletions leading to later onset syndromes. A wide spectrum of POLG1 mutations is reported in the literature and it is considered the main gene responsible for inherited mitochondrial disorders; indeed, about $2 \%$ of the MD population carries these mutations. Among POLG-related disorders, cerebellar and sensory ataxia are prominent clinical features. Different abbreviations have been coined to distinguish POLG1-related ataxia in the context of a sensory neuropathy: MIRAS has been used to define a mitochondrial recessive ataxia syndrome; SANDO for sensory ataxia neuropathy, dysarthria, and ophthalmoplegia; and MEMSA for myoclonic epilepsy, myopathy, and sensory ataxia. A different form characterized by spinocerebellar ataxia with epilepsy is known as SCAE ${ }^{[115]}$. More than 100 mutations in POLG have been described but four common mutations (A467T, W748S, G848S, and $T 251$ I-P587L) are frequently reported ${ }^{[115,116]}$.

Mutations in SPG7 encoding paraplegin, a component of the mitochondrial AAA protease, have been reported both in patients with recessive hereditary spastic paraplegia and in patients with a predominant ataxic presentation ${ }^{[117]}$. A strictly related gene to paraplegin is $A F G 3 L 2$ that is highly expressed in Purkinje neurons and is responsible of spinocerebellar ataxia type 28 (SCA28); the role of these proteins may explain the involvement of the cerebellum in both conditions.

Finally, it is worth mentioning some rare complex forms due to mitochondrial enzymes deficiencies, such as Aconitase 2 (ACO2) deficiency reported in severe encephalopathy with hypotonia, athetosis, seizures, optic atrophy, and retinal and cerebellar degeneration or defect of the epimerase encoded by NAXE that results in children with ataxia, cerebellar edema, spinal myelopathy, and skin lesions ${ }^{[118,119]}$.

A description of all genes will never be complete but the examples selected above, although arbitrary, reinforce the concept that MoD are often combined and manifest in variable clinical scenarios that imply diagnostic and management challenges even for physicians expert in the field.

\section{Therapeutic interventions for MoD in MD}

Over the last decades, significant progress has been achieved to improve the diagnosis of MD and to better understand the pathogenic mechanisms underlying these disorders, but thus far therapeutic options are very limited and mostly not specific ${ }^{[120]}$.

Among MD, some treatable disorders have to be considered and their diagnosis is critical to start early a specific treatment. In CoQ10 deficiency syndromes, oral supplementation with high-dose CoQ10 ameliorates the clinical condition and changes the disease progression.

Besides primary CoQ10 deficiencies, CoQ10 is largely used in combination with a variety of vitamins and cofactors such as L-carnitine, creatine, and riboflavin, a so-called "mitochondrial cocktail", in all patients with MD. Although these treatments are based on the current knowledge of MD pathomechanisms, their use is not standardized and data on clinical efficacy are quite poor.

About the management of MoD, supportive treatment of the different features (e.g., myoclonus, parkinsonism, and dystonia) in subjects with MD is not dissimilar from the treatment of the same symptoms in the general population but physicians should take into account some cautions because of the well-known mitochondrial toxicity of some drugs, e.g., valproate, aminoglycosides, etc. 
Levodopa and oral baclofen are the most common reported medications to treat dystonia, both drugs being well tolerated but the efficacy is variable. Treatments with intrathecal baclofen or deep brain stimulation are not yet reported in the literature ${ }^{[120]}$.

Botulinum neurotoxin injections are useful to treat focal or multifocal dystonia. Other medications such as oral baclofen, tizanidine, or trihexyphenidyl have been reported in few patients and data on their efficacy are inconsistent ${ }^{[8]}$. A positive response for myoclonus may be seen with levetiracetam, clonazepam, or valproate, although for the latter particular attention should be paid in patients with MD because of its possible toxicity $^{[121]}$.

MP patients benefit from dopaminergic treatment, although few cases have not had an optimal response to L-DOPA and early onset dyskinesia has also been reported. It is evidenced that symmetrical nigrostriatal degeneration at DAT-SCAN predicts a better response to treatment ${ }^{[14]}$.

From a perspective point of view, several attempts have been made to counteract mitochondrial dysfunctions. Many compounds active in mitochondrial biogenesis by activation of the pathway peroxisome proliferatoractivated receptor $\gamma$, as well as its coactivator 1a (PGC1 $\alpha$ ), have been tested in patients with PD but most of them fail to produce a real benefit. Among them, some antidiabetic drugs acting on these mechanisms, such as pioglitazone and exenatide, have been tested in preclinical studies as well as clinical trials on PD patients, but their efficacy is uncertain ${ }^{[8]}$.

Preclinical studies have shown benefit to boosting mitochondrial function but translation in humans is still far from being a reality.

\section{CONCLUSION}

Movement disorders are part of the clinical spectrum of MD among both pediatric and adult patients usually in the context of a mitochondrial multisystem presentation. Data on the true incidence of MoD are quite limited because no population-based studies are available. In children, dystonia and ataxia are the most common $\mathrm{MoD}$, more frequently associated with mtDNA mutations. In adults, myoclonus, ataxia, and parkinsonism are reported either in mtDNA mutations syndromes or in nDNA mutations, causing alterations of mtDNA maintenance. Basal ganglia and cerebellum degeneration appear to be the neuropathological substrate of MoD but the pathological mechanisms need still to be clarified. "Mitochondrial parkinsonism" is an emerging topic and should be suspected in patients manifesting an akinetic syndrome with PEO and myopathic signs. Treatment of these disorders is largely empirical and large cohort studies are necessary to improve the management of MD patients with MoD.

\section{DECLARATIONS}

\section{Authors' contributions}

Made substantial contributions to conception and design of the study and performed data analysis and interpretation: Musumeci O, Toscano A

Performed data acquisition, technical, and material support: Oteri $\mathrm{R}$

\section{Availability of data and materials}

Not applicable.

\section{Financial support and sponsorship}

This work was supported by Telethon (GUP9004, GSP16001) 


\section{Conflicts of interest}

All authors declared that there are no conflicts of interest.

\section{Ethical approval and consent to participate}

Not applicable.

\section{Consent for publication}

Not applicable.

\section{Copyright}

(c) The Author(s) 2020.

\section{REFERENCES}

1. Schaefer AM, McFarland R, Blakely EL, He L, Whittaker RG, et al. Prevalence of mitochondrial DNA disease in adults. Ann Neurol 2008;63:35-9.

2. Schapira AHV. Mitochondrial disorders. Lancet 2012;379:1825-34.

3. DiMauro S, Schon EA, Carelli V, Hirano M. The clinical maze of mitochondrial neurology. Nat Rev Neurol 2013;9:429-44.

4. McFarland R, Taylor RW, Turnbull DM. A neurological perspective on mitochondrial disease. Lancet Neurol 2010;9:829-40.

5. Hanna MG, Bhatia KP. Movement disorders and mitochondrial dysfunction. Curr Opin Neurol 1997;10:351-6.

6. Tranchant C, Anheim M. Movement disorders in mitochondrial diseases. Rev Neurol 2016;172:524-9.

7. Ghaoui R, Sue CM. Movement disorders in mitochondrial disease. J Neurol 2018;265:1230-40.

8. Martikainen MH, Ng YS, Gorman GS, Alston CL, Blakely EL, et al. Clinical, genetic, and radiological features of extrapyramidal movement disorders in mitochondrial disease. JAMA Neurol 2016;73:668-74.

9. Moustris A, Edwards MJ, Bhatia KP. Movement disorders and mitochondrial disease. Handb Clin Neurol 2011;100:173-92.

10. Flønes IH, Tzoulis C. Movement disorders in mitochondrial disease: a clinicopathological correlation. Curr Opin Neurol 2018;31:472-83.

11. Truong DD, Harding AE, Scaravilli F, Smith SJ, Morgan-Hughes JA, et al. Movement disorders in mitochondrial myopathies. A study of nine cases with two autopsy studies. Mov Disord 1990;5:109-17.

12. Macaya A, Munell F, Burke RE, De Vivo DC. Disorders of movement in Leigh syndrome. Neuropediatrics 1993;24:60-7.

13. Papandreou A, Rahman S, Fratter C, Ng J, Meyer E, et al. Spectrum of movement disorders and neurotransmitter abnormalities in paediatric POLG disease. J Inherit Metab Dis 2018;41:1275-83.

14. Schreglmann SR, Riederer F, Galovic M, Ganos C, Kägi G, et al. Movement disorders in genetically confirmed mitochondrial disease and the putative role of the cerebellum. Mov Disord 2018;33:146-55.

15. Fahn S. Classification of movement disorders Mov Disord 2011;26:947-57.

16. LeDoux MS. The genetics of dystonias. Adv Genet 2012;79:35-85.

17. Marras C, Lang A, van de Warrenburg BP, Sue CM, Tabrizi SJ, et al. Nomenclature of genetic movement disorders: recommendations of the international Parkinson and movement disorder society task force. Mov Disord 2016;31:436-57.

18. Chang X, Wu Y, Zhou J, Meng H, Zhang W, et al. A meta-analysis and systematic review of Leigh syndrome: clinical manifestations, respiratory chain enzyme complex deficiency, and gene mutations. Medicine 2020;99:e18634.

19. Naess K, Freyer C, Bruhn H, Wibom R, Malm G, et al. mtDNA mutations are a common cause of severe disease phenotypes in children with Leigh syndrome. Biochim Biophys Acta 2009;1787:484-90.

20. Sofou K, De Coo IF, Isohanni P, Ostergaard E, Naess K, et al. A multicenter study on Leigh syndrome: disease course and predictors of survival. Orphanet J Rare Dis 2014;9:52.

21. Zhang Y, Yang YL, Sun F, Cai X, Qian N, et al. Clinical and molecular survey in 124 Chinese patients with Leigh or Leigh like syndrome. J Inherit Metab Dis 2007;30:265.

22. Sofou K, de Coo IFM, Ostergaard E, Isohanni P, Naess K, et al. Phenotype-genotype correlations in Leigh syndrome: new insights from a multicentre study of 96 patients. J Med Genet 2018;55:21-27.

23. Piekutowska-Abramczuk D, Popowska E, Pronicki M, Karczmarewicz E, Tylek-Lemanska D, et al. High prevalence of SURF1 c.845_846delct mutation in Polish Leigh patients. Eur J Paediatr Neurol 2009; 13:146-53.

24. Tolomeo D, Rubegni A, Severino M, Pochiero F, Bruno C, et al. Clinical and neuroimaging features of the m.10197G $>$ A mtDNA mutation: new case reports and expansion of the phenotype variability. J Neurol Sci 2019;399:69-75.

25. Ugalde C, Triepels RH, Coenen MJ, van den Heuvel LP, Smeets R, et al. Impaired complex I assembly in a Leigh syndrome patient with a novel missense mutation in the ND6 gene. Ann Neurol 2003,54:665-9.

26. Wang K, Takahashi Y, Gao ZL, Wang GX, Chen XW, et al. Mitochondrial ND3 as the novel causa tive gene for Leber hereditary optic neuropathy and dystonia. Neurogenetics 2009;10:337-45.

27. Gropman A, Chen TJ, Perng CL, Krasnewich D, Chernoff E, et al. Variable clinical manifestation of homoplasmic G14459A mitochondrial DNA mutation. Am J Med Genet A 2004;124A:377-82.

28. Rahman S, Thorburn D. Nuclear gene-encoded leigh syndrome overview. In: Adam MP, Ardinger HH, Pagon RA, Wallace SE, Bean LJH, 
et al, editors. GeneReviews ${ }^{\circledR}$ [Internet]. Seattle: University of Washington; 2015. pp. 1993-2020.

29. Wedatilake Y, Brown RM, McFarland R, Yaplito-Lee J, Morris AA, et al. SURF1 deficiency: a multi-centre natural history study. Orphanet J Rare Dis 2013;8:96.

30. Baide-Mairena H, Gaudó P, Marti-Sánchez L, Emperador S, Sánchez-Montanez A, et al. Mutations in the mitochondrial complex I assembly factor NDUFAF6 cause isolated bilateral striatal necrosis and progressive dystonia in childhood. Mol Genet Metab 2019;126:250-8.

31. Carrozzo R, Dionisi-Vici C, Steuerwald U, Lucioli S, Deodato F, et al. SUCLA2 mutations are associated with mild methylmalonic aciduria, Leigh-like encephalomyopathy, dystonia and deafness. Brain 2007;130:862-74.

32. Desai R, Frazier AE, Durigon R, Patel H, Jones AW, et al. ATAD3 gene cluster deletions cause cerebellar dysfunction associated with altered mitochondrial DNA and cholesterol metabolism. Brain 2017;140:1595-610.

33. Maas RR, Iwanicka-Pronicka K, Kalkan Ucar S, Alhaddad B, AlSayed M, et al. Progressive deafness-dystonia due to SERAC1 mutations: a study of 67 cases. Ann Neurol 2017;82:1004-15.

34. Heimer G, Kerätär JM, Riley LG, Balasubramaniam S, Eyal E, et al. MECR mutations cause childhood onset dystonia and optic atrophy, a mitochondrial fatty acid synthesis disorder. Am J Hum Genet 2016;99:1229-44.

35. Engl G, Florian S, Tranebjaerg L, Rapaport D. Alterations in expression levels of deafness dystonia protein 1 affect mitochondrial morphology. Hum Mol Genet 2012;21:287-99.

36. Aguirre LA, del Castillo I, Macaya A, Medá C, Villamar M, et al. A novel mutation in the gene encoding TIMM8a, a component of the mitochondrial protein translocase complexes, in a Spanish familial case of deafness-dystonia (Mohr-Tranebjaerg) syndrome. Am J Med Genet A 2006;140:392-7.

37. Meire FM, Van Coster R, Cochaux P, Obermaier-Kusser B, Candaele C, et al. Neurological disorders in members of families with Leber's hereditary optic neuropathy (LHON) caused by different mitochondrial mutations. Ophthalmic Genet 1995;16:119-26.

38. Nikoskelainen EK, Marttila RJ, Huoponen K, Juvonen V, Lamminen T, et al. Leber's 'plus': neurological abnormalities in patients with Leber's hereditary optic neuropathy. J Neurol Neurosurg Psychiatry 1995;59:160-4.

39. Simon DK, Friedman J, Breakefield XO, Jankovic J, Brin MF, et al. A heteroplasmic mitochondrial complex I gene mutation in adultonset dystonia. Neurogenetics 2003;4:199-205.

40. Jun AS, Brown MD, Wallace DC. A mitochondrial DNA mutation at nucleotide pair 14459 of the NADH dehydrogenase subunit 6 gene associated with maternally inherited Leber hereditary optic neuropathy and dystonia. Proc Natl Acad Sci USA 1994;91:6206-10.

41. Mercuri MA, White H, Oliveira C. Vision loss and symmetric basal ganglia lesions in leber hereditary optic neuropathy. J Neuroophthalmol 2017;37:411-3.

42. Marie SK, Carvalho AA, Fonseca LF, Carvalho MS, Reed UC, et al. Kearns-Sayre syndrome 'plus'. Classical clinical findings and dystonia. Arq Neuropsiquiatr 1999;57:1017-102.

43. Sudarsky L, Plotkin GM, Logigian EL, Johns DR. Dystonia as a presenting feature of the 3243 mitochondrial DNA mutation. Mov Disord 1999;14:488-91.

44. Peng Y, Crumley R, Ringman JM. Spasmodic dysphonia in a patient with the A to G transition at nucleotide 8344 in mitochondrial DNA. Mov Disord 2003;18:716-8.

45. Hinnell C, Haider S, Delamont S, Clough C, Hadzic N, et al. Dystonia in mitochondrial spinocerebellar ataxia and epilepsy syndrome associated with novel recessive POLG mutations. Mov Disord 2012;27:162-3.

46. Morimoto N, Nagano I, Deguchi K, Murakami T, Fushimi S, et al. Leber hereditary optic neuropathy with chorea and dementia resembling Huntington disease. Neurology 2004;63:2451-452.

47. Nakagaki H, Furuya J, Santa Y, Nagano S, Araki E, et al. A case of MELAS presenting juvenile-onset hyperglycemic chorea-ballism. Rinsho Shinkeigaku 2005;45:502-5.

48. Kang JH, Kang SY, Choi JC, Lee SS, Kim JS. Chorea triggered by hyperglycemia in a maternally inherited diabetes and deafness (MIDD) patient with the A3243G mutation of mitochondrial DNA and basal ganglia calcification. J Neurol 2005;252:103-5.

49. Lahiri D, Sawale VM, Banerjee S, Dubey S, Roy BK, et al. Chorea-ballism as a dominant clinical manifestation in heteroplasmic mitochondrial encephalopathy, lactic acidosis, and stroke-like episodes syndrome with A3251G mutation in mitochondrial genome: a case report. J Med Case Rep 2019;13:63.

50. Finsterer J. Parkinson syndrome as a manifestation of mitochondriopathy. Acta Neurol Scand 2002;105:384-9.

51. Finsterer J. Parkinson's syndrome and Parkinson's disease in mitochondrial disorders. Mov Disord 2011;26:784-91.

52. Thyagarajan D, Bressman S, Bruno C, Przedborski S, Shanske S, et al. A novel mitochondrial 12SrRNA point mutation in parkinsonism, deafness, and neuropathy. Ann Neurol 2000;48:730-6.

53. Horvath R, Kley RA, Lochmuller H, Vorgerd M. Parkinson syndrome, neuropathy, and myopathy caused by the mutation A8344G (MERRF) in tRNALys. Neurology 2007;68:568.

54. Martikainen MH, Kytovuori L, Majamaa K. Juvenile parkinsonism, hypogonadism and Leigh-like MRI changes in a patient with m.4296G > A mutation in mitochondrial DNA. Mitochondrion 2013;13:83-6.

55. De Coo IF, Renier WO, Ruitenbeek W, Ter Laak HJ, Bakker M, et al. A 4-base pair deletion in the mitochondrial cytochrome b gene associated with parA 4-base pair deletion in the mitochondrial cytochrome b gene associated with parkinsonism/MELAS overlap syndrome. Ann Neurol 1999;45:130-3.

56. Rana M, de Coo I, Diaz F, Smeets H, Moraes CT. An out-of-frame cytochrome b gene deletion from a patient with parkinsonism is associated with impaired complex III assembly and an increase in free radical production. Ann Neurol 2000;48:774-81.

57. Simon DK, Pulst SM, Sutton JP, Browne SE, Beal MF, et al. Familial multisystem degeneration with parkinsonism associated with the 
11778 mitochondrial DNA mutation. Neurology 1999;53:1787-93.

58. Vital C, Julien J, Martin-Negrier ML, Lagueny A, Ferrer X, et al. Parkinsonism in a patient with Leber hereditary optic neuropathy (LHON). Rev Neurol 2015;171:679-80.

59. Tzoulis C, Schwarzlmüller T, Biermann M, Haugarvoll K, Bindoff LA. Mitochondrial DNA homeostasis s essential for nigrostriatal integrity. Mitochondrion 2016;28:33-7.

60. Luoma P, Melberg A, Rinne JO, Kaukonen JA, Nupponen NN, et al. Parkinsonism, premature menopause and mitochondrial DNA polymerase gamma mutations: clinical and molecular genetic study. Lancet 2004;364:875-82.

61. Baloh RH, Salavaggione E, Milbrandt J, Pestronk A. Familial parkinsonism and ophthalmoplegia from a mutation in the mitochondrial DNA helicase twinkle. Arch Neurol 2007;64:998-1000.

62. Carelli V, Musumeci O, Caporali L, Zanna C, La Morgia C, et al. Syndromic parkinsonism and dementia associated with OPA1 missense mutations. Ann Neurol 2015;78:21-38.

63. Garone C, Rubio JC, Calvo SE, Naini A, Tanji K, et al. MPV17 mutations causing adult-onset multisystemic disorder with multiple mitochondrial DNA deletions. Arch Neurol 2012;69:1648-51.

64. Van Maldergem L, Besse A, De Paepe B, Blakely EL, Appadurai V, et al. POLG2 deficiency causes adult-onset syndromic sensory neuropathy, ataxia and parkinsonism. Ann Clin Transl Neurol 2016;4:4-14.

65. Mancuso M, Filosto M, Oh SJ, DiMauro S. A novel polymerase gamma mutation in a family with ophthalmoplegia, neuropathy, and Parkinsonism. Arch Neurol 2004;61:1777-9.

66. Davidzon G, Greene P, Mancuso M, Klos KJ, Ahlskog JE, et al. Early-onset familial parkinsonism due to POLG mutations. Ann Neurol 2006;59:859-62.

67. Betts-Henderson J, Jaros E, Krishnan KJ, Perry RH, Reeve AK, et al. Alpha-synuclein pathology and Parkinsonism associated with POLG1 mutations and multiple mitochondrial DNA deletions. Neuropathol Appl Neurobiol 2009;35:120-4.

68. Invernizzi F, Varanese S, Thomas A, Carrara F, Onofrj M, et al. Two novel POLG1 mutations in a patient with progressive external ophthalmoplegia, levodopa-responsive pseudo-orthostatic tremor and parkinsonism. Neuromuscul Disord 2008;18:460-4.

69. Remes AM, Hinttala R, Kärppä M, Soini H, Takalo R, et al. Parkinsonism associated with the homozygous W748S mutation in the POLG1 gene. Parkinsonism Relat Disord 2008;14:652-4.

70. Hudson G, Schaefer AM, Taylor RW, Tiangyou W, Gibson A, et al. Mutation of the linker region of the polymerase gamma-1 (POLG1) gene associated with progressive external ophthalmoplegia and Parkinsonism. Arch Neurol 2007;64:553-7.

71. Synofzik M, Asmus F, Reimold M, Schöls L, Berg D. Sustained dopaminergic response of parkinsonism and depression in POLGassociated parkinsonism. Mov Disord 2010;25:243-5.

72. Galassi G, Lamantea E, Invernizzi F, Tavani F, Pisano I, et al. Additive effects of POLG1 and ANT1 mutations in a complex encephalomyopathy. Neuromuscul Disord 2008;18:465-70

73. Sato K, Yabe I, Yaguchi H, Nakano F, Kunieda Y, et al. Genetic analysis of two Japanese families with progressive external ophthalmoplegia and parkinsonism. J Neurol 2011;258:1327-32.

74. Van Goethem G, Löfgren A, Dermaut B, Ceuterick C, Martin JJ, et al. Digenic progressive external ophthalmoplegia in a sporadic patient: recessive mutations in POLG and C10orf2/Twinkle. Hum Mutat 2003;22:175-6.

75. Vandenberghe W, Van Laere K, Debruyne F, Van Broeckhoven C, Van Goethem G. Neurodegenerative parkinsonism and progressive external ophthalmoplegia with a Twinkle mutation. Mov Disord 2009;24:308-9.

76. Kiferle L, Orsucci D, Mancuso M, Lo Gerfo A, Petrozzi L, et al. Twinkle mutation in an Italian family with external progressive ophthalmoplegia and parkinsonism: a case report and an update on the state of art. Neurosci Lett 2013;556:1-4.

77. Brandon BR, Diederich NJ, Soni M, Witte K, Weinhold M, et al. Autosomal dominant mutations in POLG and C10orf2: association with late onset chronic progressive external ophthalmoplegia and Parkinsonism in two patients. J Neurol 2013;260:1931-3.

78. De la Casa-Fages B, Fernández-Eulate G, Gamez J, Barahona-Hernando R, Morís G, García-Barcina M, et al. Parkinsonism and spastic paraplegia type 7: expanding the spectrum of mitochondrial Parkinsonism. Mov Disord 2019;34:1547-61.

79. Wilcox RA, Churchyard A, Dahl HH, Hutchinson WM, Kirbi DM, et al. Levodopa response in Parkinsonism with multiple mitochondrial DNA deletions. Mov Disord 2007;22:1020-3.

80. Chalmers RM, Brockington M, Howard RS, Lecky BR, Morgan-Hughes JA, et al. Mitochondrial encephalopathy with multiple mitochondrial DNA deletions: a report of two families and two sporadic cases with unusual clinical and neuropathological features. J Neurol Sci 1996;143:45.

81. Siciliano G, Mancuso M, Ceravolo R, Lombardi V, Iudice A, et al. Mitochondrial DNA rearrangements in young onset parkinsonism: two case reports. J Neurol Neurosurg Psychiatry 2001;71:685-7.

82. Casali C, Bonifati V, Santorelli FM, Casari G, Fortini D, et al. Mitochondrial myopathy, parkinsonism, and multiple mtDNA deletions in a Sephardic Jewish family. Neurology 2001;56:802-5.

83. Lehmann Urban D, Motlagh Scholle L, Alt K, Ludolph AC, Rosenbohm A. Camptocormia as a novel phenotype in a heterozygous POLG2 mutation. Diagnostics 2020;10:E68.

84. Ma L, Mao W, Xu E, Cai Y, Wang C, et al. Novel POLG mutation in a patient with early-onset parkinsonism, progressive external ophthalmoplegia and optic atrophy Int J Neurosci 2019;130:319-21.

85. Giannoccaro MP, La Morgia C, Rizzo G, Carelli V. Mitochondrial DNA and primary mitochondrial dysfunction in Parkinson's disease. Mov Disord 2017;32:346-63.

86. Jiang X, Jin T, Zhang H, Miao J, Zhao X, et al. Current progress of mitochondrial quality control pathways underlying the pathogenesis of Parkinson's disease. Oxid Med Cell Longev 2019:4578462. 
87. Wong YC, Luk K, Purtell K, Burke Nanni S, Stoessl AJ, et al. Neuronal vulnerability in Parkinson disease: Should the focus be on axons and synaptic terminals? Mov Disord 2019;34:1406-22.

88. Ammal Kaidery N, Thomas B. Current perspective of mitochondrial biology in Parkinson's disease. Neurochem Int 2018;117:91-113.

89. Sanger TD, Chen D, Fehlings DL, Hallett M, Lang AE, et al. Definition and classification of hyperkinetic movements in childhood. Mov Disord 2010; 25:1538-49.

90. Mancuso M, Orsucci D, Angelini C, Bertini E, Catteruccia M, et al. Myoclonus in mitochondrial disorders. Mov Disord 2014;29:722-8.

91. Chen RS, Huang CC, Lee CC, Wai YY, Hsi MS, et al. Overlapping syndrome of MERRF and MELAS: molecular and neuroradiological studies. Acta Neurol Scand 1993;87:494-8.

92. Brackmann F, Abicht A, Ahting U, Schroder R, Trollmann R. Classical MERRF phenotype associated with mitochondrial tRNA(Leu) (m.3243A > G) mutation. Eur J Pediatr 2012;171:859-62.

93. La Morgia C, Achilli A, Iommarini L, Barboni P, Pala M, et al. Rare mtDNAvariants in Leber hereditary o ptic neuropathy families with recurrence of myoclonus. Neurology 2008;70:762-77.

94. Dermaut B, Seneca S, Dom L, Smets K, Ceulemans L, et al. Progressive myoclonic epilepsy as an adult-onset manifestation of Leigh syndrome due to m.14487T > C. J Neurol Neurosurg Psychiatry 2010;81:90-93.

95. Van Goethem G, Mercelis R, Lofgren A, Van Goethem G, Mercelis R, et al. Patient homozygous for a recessive POLG mutation presents with features of MERRF. Neurology 2003;61:1811-3.

96. Wong LJ, Naviaux RK, Brunetti-Pierri N, Zhang Q, Schmitt ES, et al. Molecular and clinical genetics of mitochondrial diseases due to POLG mutations. Hum Mutat 2008;29:E15072.

97. Mignot C, Apartis E, Durr A, Marques Lourenço C, Charles P, et al. Phenotypic variability in ARCA2 and identification of a core ataxic phenotype with slow progression. Orphanet J Rare Dis 2013;8:173.

98. Zeviani M, Simonati A, Bindoff LA. Ataxia in mitochondrial disorders. Handb Clin Neurol 2012;103:359-72.

99. Tanji K, Vu TH, Schon EA, DiMauro S, Bonilla E. Kearns-Sayre syndrome: unusual pattern of expression of subunits of the respiratory chain in the cerebellar system. Ann Neurol 1999;45:377-83.

100. Lombes A, Mendell JR, Nakase H, Barohn RJ, Bonilla E, et al. Myoclonic epilepsy and ragged-red fibers with cytochrome oxidase deficiency: neuropathology, biochemistry, and molecular genetics. Ann Neurol 1989;26:1231-60.

101. Mancuso M, Orsucci D, Angelini C, Bertini E, Carelli V, et al. Phenotypic heterogeneity of the 8344A > G mtDNA "MERRF" mutation. Neurology 2013;80:2049-54.

102. DiMauro S, Hirano M. MELAS. In: Adam MP, Ardinger HH, Pagon RA, Wallace SE, Bean LJH, Stephens K, Amemiya A, editors. GeneReviews. Seattle (WA): University of Washington; 1993.

103. Garone C, Hirano M, Quinzii C. CoQ10 deficiencies and MNGIE: two treatable mitochondrial disorders. Biochim Biophys Acta 2012;1820:625-31.

104. Quinzii C, Naini A, Salviati L, Trevisson E, Navas P, et al. A mutation in para- hydroxybenzoate-polyprenyl transferase (COQ2) causes primary coenzyme Q10 deficiency. Am J Hum Genet 2006;78:345-9.

105. Musumeci O, Naini A, Slonim AE, Skavin N, Hadjigeorgiou GL, et al. Familial cerebellar ataxia with muscle coenzyme Q10 deficiency. Neurology 2001;56:849-855.

106. Lagier-Tourenne C, Tazir M, López LC, Quinzii CM, Assoum M, et al. ADCK3, an ancestral kinase, is mutated in a form of recessive ataxia associated with coenzyme Q10 deficiency. Am J Hum Genet 2008;82:661-72.

107. Barca E, Musumeci O, Montagnese F, Marino S, Granata F, et al. Cerebellar ataxia and severe muscle CoQ10 deficiency in a patient with a novel mutation in ADCK3. Clin Genet 2016;90:156-60.

108. Hudson G, Amati-Bonneau P, Blakely EL, Stewart JD, He L, et al. Mutation in OPA1 causes dominant optic atrophy with external ophthalmoplegia, ataxia, deafness and multiple mitochondrial DNA deletions: a novel disorder of mtDNA maintenence. Brain 2008;131:329-37.

109. Szklarczyk R, Wanschers BF, Nijtmans LG, Rodenburg RJ, Zschocke J, et al. A mutation in the FAM36A gene, the human ortholog of COX20, impairs cytochrome $\mathrm{c}$ oxidase assembly and is associated with ataxia and muscle hypotonia. Hum Mol Genet 2013;22:656-67.

110. Fratter C, Raman P, Alston CL, Blakely EL, Craig K, et al. RRM2B mutations are frequent in familial PEO with multiple mtDNA deletions. Neurology 2011;76:2032-4.

111. Ghezzi D, Arzuffi P, Zordan M, Da Re C, Lamperti C, et al. Mutations in TTC19 cause mitochondrial complex III deficiency and neurological impairment in humans and flies. Nat Genet 2011;43:259-63

112. Nikali K, Suomalainen A, Saharinen J, Kuokkanen M, Spelbrink JN, et al. Infantile onset spinocerebellar ataxia is caused by recessive mutations in mitochondrial proteins Twinkle and Twinky. Hum Mol Genet 2005;14:2981-90.

113. Rahman S, Copeland WC. POLG-related disorders and their neurological manifestations. Nat Rev Neurol 2019;15:40-52

114. Li K, Jin R, Wu X. Whole-exome sequencing identifies rare compound heterozygous mutations in the MSTO1 gene associated with cerebellar ataxia and myopathy. Eur J Med Genet 2020;63:103623.

115. Hakonen AH, Heiskanen S, Juvonen V, Lappalainen I, Luoma PT, et al. Mitochondrial DNA polymerase W748S mutation: a common cause of autosomal recessive ataxia with ancient European origin. Am J Hum Genet 2005;77:430-441.

116. Tzoulis C, Engelsen BA, Telstad W, Aasly J, Zeviani M, et al. The spectrum of clinical disease caused by the A467T and W748S POLG mutations: a study of 26 cases. Brain 2006;129:1685-92.

117. Pfeffer G, Pyle A, Griffin H, Miller J, Wilson V, et al. SPG7 mutations are a common cause of undiagnosed ataxia. Neurology 2015;84:1174-6.

118. Sharkia R, Wierenga KJ, Kessel A, Azem A, Bertini E, et al. Clinical, radiological, and genetic characteristics of 16 patients with ACO2 
gene defects: Delineation of an emerging neurometabolic syndrome. J Inherit Metab Dis 2019;42:264-75

119. Trinh J, Imhoff S, Dulovic-Mahlow M, Kandaswamy KK, Tadic V, et al. Novel NAXE variants as a cause for neurometabolic disorder: implications for treatment. J Neurol 2020;267:770-782.

120. Orsucci D, Ienco EC, Siciliano G, Mancuso M. Mitochondrial disorders and drugs: what every physician should know. Drugs Context 2019;8:212588.

121. Mancuso M, Galli R, Pizzanelli C, Filosto M, Siciliano G, et al. Antimyoclonic effect of levetiracetam in MERRF syndrome. J Neurol Sci 2006;243:97-9. 